\title{
EMPIRICAL EVIDENCE ON THE IMPACT OF MONETARY POLICY ON NATIONAL ECONOMIC GROWTH
}

\author{
Abd Kadir Arno ${ }^{1}$, Nirwana Halide ${ }^{2}$, Iksan Purnama ${ }^{3}$, Akbar Sabani ${ }^{4}$ \\ ${ }^{1}$ Faculty of Islamic Economics and Business, Palopo State Islamic Institute, South Sulawesi \\ email: abdulkadir.arno@iainpalopo.ac.id, \\ ${ }^{2}$ Sharia Faculty, Palopo State Islamic Institute, South Sulawesi. \\ email: nirwanahalide27@iainpalopo.ac.id
}
${ }^{3}$ Faculty of Islamic Economics and Business, Palopo State Islamic Institute, South Sulawesi email: m.ikhsan_purnama@iainpalopo.ac.id

${ }^{4}$ Faculty of Islamic Economics and Business, Palopo State Islamic Institute, South Sulawesi email: akbarsabani@iainpalopo.ac.id

\begin{abstract}
This article discusses empirical evidence of monetary policy's impact on national economic growth in the decade 2010-2019. This article is analyzed using a regression analysis tool. This article concludes that 1) the interest rate (BI Rate) has an impact rate on national economic growth in the decade 2010-2019 of only 7 percent. Impact of US \$ exchange rate on the domestic economic growth of only 90 percent 3) Impact of the amount of money in circulation on the national economic growth of only 76.8 percent, 4) Impact of inflation rate on the domestic economic growth of only 4.3 percent 5) impact of total investment in national economic growth is only 60.8 percent. Thus the main objective of monetary policy is more emphasis on price stability. With the first consideration, with output determined by long-term economic capacity, all systems that encourage economic growth will create inflation so that it will not affect real economic growth. Second, the rational financial agent understands that policymakers' actions in supporting the economic growth that helps increase can lead to time consistency problems. Third, monetary policy influencing economic variables takes a long time and has a lag. Fourth, price stability can encourage creating a better economic climate because it will reduce costs from inflation
\end{abstract}

Keywords: Monetary Policy, Interest and Exchange Rates, Money Supply, Inflation, Investment, Economic Growth

\section{Introduction}

The main problem in monetary theory is whether changes in the money supply or the growth rate of money can have a lasting effect on economic variables. Specifically, the question of the so-called super-neutrality of funds - whether permanent changes in money growth do not have a long-term impact on real interest rates capital accumulation, and output growth - has been extensive theoretical analysis from the first.

In the current era of globalization, where other countries' financial events greatly influence a country's economic activities, external factors will affect the government in determining policies, both fiscal and monetary policies. Cioran (2014) suggested that financial business is an integral part of an economy so that economic growth cannot be analyzed without involving monetary problems.

Monetary policy plays an essential role in economic growth if the procedure is implemented effectively to maintain price stability and keep inflation at a minimum level. This goal is achieved through a process in which a country's monetary authority 
controls the money supply, money availability, and interest rate. Hameed \& Amin, (2011) explained that monetary policy depends on the relationship between the interest rate in an economy (i.e., the demand for money and the total amount of money in circulation so that the monetary authority uses this monetary policy variable to influence economic growth, inflation exchange rates with other countries. Monetary policy is uniquely able to change long-term price levels through the process of creating money.

Monetary policy with an interest rate that is by setting an ideal interest rate to encourage investment activities. If the interest rate increases beyond the set rate, the central bank will lower the interest rate to the specified level. Whereas monetary policy that uses the money supply as an intermediate target has a positive impact in the form of a stable price

The effects of monetary policy on real economic activity are limited and temporary, although poorly implemented fiscal policies can continue to hamper economic growth. Economic growth is also driven by factors such as technological change, population growth, and the accumulation of human capital. In economic growth, what is needed is monetary stability. The most important contribution that the central bank can make to growth is low and stable inflation.

To reduce instability in the economy, the government will conduct monetary policy through the central bank. According to Nanga (2005: 180), fiscal policy undertaken by the government is by controlling the interest rates and the money supply (money supply). This policy influences the development of money supply, interest rates, lending rates, and exchange rates, which are monetary variables in achieving the desired targets, namely economic growth, job opportunities, price stability, and balance of payments balance. The central bank, as a monetary authority will regulate the balance between money supply and inventory. This is done so that inflation can be controlled, full employment opportunities are achieved, and fluency in the supply/distribution of goods

The impact of monetary policy on real economic growth has become an area of debate in macroeconomics. (Bernanke and Gertler, 1995) Discussions conventionally state whether changes in interest rates affect real economic variables, and, if so, how much influence. This debate is even more prominent when it comes to the regional level, because monetary policy is inherently a national policy, whereas local monetary policy shows different structures and characteristics. Therefore, they can respond impulsively to a uniform financial system. As a result, it will have distribution implications throughout the region, because economic activity in the area can be stimulated by monetary policy, (Ridhwan et al., 2008)

To uncover the problem of the impact of monetary policy, many studies have sought to identify it. For example, Carlino and DeFina (1998, 1999), and Owyang and Wall (2004) examined in the United States, while Ramaswamy and Sløk (1998) and Clements et al. (2001) have studied European countries. In general, their findings show different effects in responding to monetary policy. Other studies, especially in European countries, have concluded that their impact in European nations is very similar (Peersman, 2004). These conflicting findings tend to show that there are still many different views about the actual effect of monetary policy.

This article aims to analyze and illustrate, namely: 1) whether empirically the average annual interest rate has an impact on national economic growth, 2) whether empirically the average exchange rate growth (us dollar exchange rate) affects national growth economy, 3) does the empirical average growth of the money supply have an impact on 
domestic economic growth, 4) does the observed average inflation rate growth have an effect on national economic growth 5) whether empirically the average investment growth rate affects economic growth nationally.

\section{Literature Review}

\section{Monetary Policy}

Monetary policy is the monetary authorities' efforts, namely the Central Bank, to influence the development of financial variables for the achievement of economic goals (Litteboy, et al. 2006: 198) and Mishkin (2004: 257). Monetary policy is an integral part of a macroeconomic policy aimed at supporting macro targets, namely high economic growth, price stability, equitable development, and balance of payments balance. Monetary policy is of two kinds, namely contractionary monetary policy and expansionary fiscal policy. Expansive monetary policy is carried out to encourage economic activity by increasing the money supply, while contractive monetary policy is carried out to slow down economic activity by reducing the money supply.

\section{Interest rate}

The interest rate used is the interest rate issued by Bank Indonesia in the form of a Bank Indonesia Certificate (SBI) in recognition of short-term debt (1-3 months) with a discount/interest system. The interest rate is determined by Bank Indonesia to control the stability of the Rupiah value. When selling SBIs, Bank Indonesia can absorb excess base money in circulation. Circulation of money that is too much in the community will cause people to tend to spend their money, which can impact the rising prices of goods, one of which is a trigger for inflation. Raise SBI interest rates, which means banks and financial institutions will be compelled to buy SBIs. The existence of high interest in SBI makes banks and financial institutions enjoy it. This will provide a higher interest rate for their products. High interest will have an impact on the allocation of investment funds for investors. One of the interest rate characteristics is that it changes quickly, which occurs in a relatively short period and has a short period. Long-term interest rates are relatively less volatile (Perlambang, 2012).

The theory that can explain the effect of interest rates on foreign exchange rate changes is the International Fisher Effect (IFE Theory) theory. This theory combines PPP theory with the Fisher Effect theory discovered by an economist named Irving Fisher. According to IFE theory, the value of currencies from countries with high-interest rates or higher than other countries will experience depreciation. If the domestic interest rate is higher than the interest rate of a foreign country, the local currency's value will depreciate, while the foreign currency will appreciate it. Exchange rates and interest rates also have close links with the terms Purchasing Power Parity (PPP). This theory is defined as the difference in the price of the same goods but sold at different rates. This theory explains that changes in relative inflation (the ratio of increase between countries) between two countries must also be balanced by changes in the exchange rate to maintain the equality of goods prices between them.

\section{Exchange Rates (Exchange Rates)}

Krugman and Obstfeld (1994: 73) define the exchange rate as the currency's price against other currencies. Exchange rates play an important role in international trade because exchange rates allow us to compare all goods and services produced by various countries. The purpose of the exchange rate is to increase the price of export products 
and, at the same time to reduce import prices measured by the exchange rate of the local currency (Todaro, 2000: 247).

The exchange rate is divided into two, namely the nominal exchange rate and the real exchange rate. The nominal exchange rate is the price of a country's currency with other countries, while the real exchange rate is the nominal exchange rate divided by domestic and foreign countries (Mankiw, 2006: 128). The real exchange rate is used as a reference to measure the competitiveness of one country with other countries. Exchange rates play an important role in international trade because exchange rates allow us to compare the prices of all goods and services produced by various countries.

To analyze the effect of a free-floating exchange rate system on the economic policy that is a small and open economy, the Billell-Fleming theory is used. The Mundell-Fleming model is a free economy version of the IS-LM model. The Mundell-Fleming and IS-LM model emphasizes the nteraction between the goods market and the money market and assumes that the price level is fixed and shows what causes short-term fluctuations in the economy. Mundell Fleming Model is a model that combines internal and external balance. Inner balance is the balance between the goods market (IS), the money market (LM). Meanwhile, the external balance is shown by the balance of payment balance (Mankiw, 2006: 332).

\section{Total Money Supply (JUB)}

Money is a stock of assets that can be used for transaction purposes and as an inventory of assets that can be immediately applied to make transactions (Mankiw, 2006: 76). Money supply (M2) includes currency in circulation, demand deposits, quasi money. The amount of money available is called the money supply.

Money supply can be defined in the narrow sense (M1) and the broad sense (M2). M1 includes currency held by the public and demand deposits (demand deposits denominated in Rupiahs), while M2 covers M1, quasi money (includesi savings, time deposits in rupiah and foreign exchange, and current accounts in foreign currencies), and securities issued by the monetary system. The domestic private sector owns them with a remaining term of up to one year.

Factors affecting the Money Supply are Net Foreign Assets (NFA) and Net Domestic Assets (NDA). Net Domestic Assets consist of, among others, Net Claims on Central Government (NCG) and Claims on other sectors (the private sector, regional governments, financial institutions, and non-financial companies) mainly in the form of loans.

According to Nopirin (2000), although in general it can be said that the money supply (JUB) can be determined directly by the Central Bank without questioning its relationship with base money, but in reality, JUB in a period is the result of the behavior of the central bank, commercial banks (including non-bank financial institutions), the community together. The main factor influencing the amount of money is the minimum reserve, but the total result of the amount of money still depends on the community's attitude. So the central bank is not so easy to regulate JUB because many factors influence it.

\section{Inflation}

An economic phenomenon that has never been lost in the long history of the economy is inflation. Where inflation is a discussion that is often discussed because it has an overall impact on the macroeconomy. Rise is an increase in prices in general and 
continuously (Mankiw, 2003: 145). This does not mean that the costs of various goods have increased by the same percentage, because these increases may not coincide. Therefore inflation is said to occur if the prices of general products increase continuously over a certain period, but if the rise occurs just once, even though a large percentage can not be inflation.

Inflation is an increase in general prices prevailing in an economy from one period to another. The rise can be seen from various levels based on the level of severity and whether, namely mild inflation ( $<10 \%$ per year), moderate increase $(10 \%-30 \%$ per year), massive inflation (30\% $-100 \%$ per year), and Hyperinflation ( $>100 \%$ per year). Meanwhile, if viewed based on the cause, an increase can be classified into four, namely the demandpull (Demand-pull inflation), the driving force of supply (Cost-push inflation), mixed rise (Mixed inflation), and expectations of Inflation (Expected Inflation).

The relationship between inflation and economici growth is if when the rise is at a controlled or stable level, it can encourage economic growth, supporting producers to increase their production further. Because production increases, producers will get more profit when the price increase is not too high. Also, an increase in production has another positive impact, namely the availability of new jobs.

Inflation will harm economic growth if an increase in inflation occurs, so people will not like to have cash. Therefore, the real value of money held is lower, and the purchasing power of money is more economical. This makes producers not eager to produce because production will not sell because the price increases are too high and consequently the production results will also decrease

\section{Investation}

Investment is one of the essential and significant factors in economic development that has been recognized by many economists. Even it is said that there is no development without investment. The primary purpose of investment activities carried out by investors or companies is to gain profits in the future. According to Sukirno (2010), finance is the investment to buy capital goods and production equipment to increase the ability to produce products and services available in the economy. Interest rates, income levels, technological advances, forecasts of future economic conditions, and other factors affect the investment size. Mankiw (2003) argues that investment consists of goods purchased for future use. Financing can be divided into three types: business fixed investment, residential investment, and inventory investment, namely goods stored by companies in warehouses including raw materials, inventory of semi-finished and finished goods.

\section{Economic growth}

Economic growth is the development of the economy by increasing the goods and services produced to increase prosperity for the community (Sukirno, 2010). So the event of an economy can be measured by economic growth. The ability of a country produce goods and services will increase from one period to another. This increased capability is due to the increase in production factors, both in quantity and quality.

Economic growth can be seen from the increase in Gross Domestic Product (GDP). Economic growth is a critical indicator for analyzing economic development that occurs in a country. Economic growth is one of the many conditions needed in the development process. Economic growth by recording an increase in the production of goods and services that occur nationally. 
Economic growth can be measured by the Gross Domestic Product (GDP) growth at constant prices. The pace of GDP growth will show a process of increasing per capita output in the long run. Emphasis is on the process because it contains dynamic elements, changes, or developments. Therefore understanding economic growth indicators will usually be seen within a specified period, for example, quarterly. The effectiveness of economic policies implemented by the government in encouraging economic activities can be assessed so that these aspects are relevant for analysis.

GDP can be calculated in two ways, namely at current prices and at constant prices. GDP at current prices illustrates the value-added of goods and services calculated using amounts in the year. GDP at regular prices represents the added value of products and services based on costs in a given year or base year. Meanwhile, according to Mankiw (2000), the calculation criteria for GDP can be divided into real GDP and nominal GDP. Practical GDP measures change in physical output in the economy between different periods by valuing all goods produced in the two periods at the same price, or constant prices. While nominal GDP measures the value of output in a period using prices in that period, or often referred to as the prevailing price.

\section{Methodology}

This article tries to review and discuss some unresolved issues by providing a quantitative survey using a meta-analysis methodology. A meta-analysis is a systematic approach to analyzing sources of variation (quantitative) in the research results obtained previously. In a previous meta-analysis, De Grauwe and Storti (2004) examined the effects of monetary policy on several variables across countries and found that methodological differences in various studies contributed significantly to financial impact variations.

The data used in this article is secondary data, which is empirical evidence sourced from official government institutions such as the Central Statistics Agency and Bank Indonesia. The data referred to in this article is data on the level of 1) interest rates, 2) the exchange rate of the dollar against the rupiah, 3) the amount of money in circulation 4) the inflation rate 5) the amount of investment and 6) national economic growth. The data analyzed are data in the past decade (2010-2019).

Analysis tools used to answer the problem formulation using growth index analysis tools, stationary tests, and regression tests using eviews and SPSS applications. Eviews application is used for statistic test of each variable and spss application is used for regression test.

\section{Result}

\section{Interest rate/BI Rate}

The interest rate is one crucial factor that needs to be considered in making investment decisions. According to Bank Indonesia, the interest rate is a cost expressed as a certain percentage in the framework of borrowing money for a specified period. Determination of the interest rate (BI rate) by Bank Indonesia (BI) is a monetary policy that aims to control Indonesia's inflation rate and, at the same time, provide a signal to investors to invest in the Indonesian capital market. Changes in interest rates (BI rate) as a reference and benchmark for the business and financial world and banking to determine the direction of business goals. This is also used by investors to analyze and assess the purchase and sale of shares by looking at the company's business sector. 
The table below is the Bank Indonesia Interest Rate (BI rate) development from 2009 to 2019, which is as follows:

Table 1

Interest rates in 2010-2019

\begin{tabular}{l|l}
\hline Year & Interest rates \\
\hline 2010 & 6.5 \\
\hline 2011 & 6.58 \\
\hline 2012 & 5.7 \\
\hline 2013 & 6.47 \\
\hline 2014 & 7.54 \\
\hline 2015 & 7.52 \\
\hline 2016 & 6 \\
\hline 2017 & 4.56 \\
\hline 2018 & 5.1 \\
\hline 2019 & 5.62 \\
\hline
\end{tabular}

Source: BI Rate, Statistics Central Board

Based on the table above, it can be seen that the interest rate (BI Rate) tends to fluctuate from year to year, where a very high decrease occurred from 2016 to 2017 with a difference of 1.44 or a reduction of 13.2 percent. The impact of the interest rate (BI Rate) on national economic growth is only 7 percent, as stated in the output of the analysis below:

Table 2

Coefficient of Interest Rate Determination of the BI Rate on Economic Growth

\begin{tabular}{l|c|r|r|r}
\hline Model & \multicolumn{1}{|c|}{$\mathbf{R}$} & R Square & \multicolumn{1}{c|}{ Adjusted R Square } & \multicolumn{1}{c}{ Std. Error of the Estimate } \\
\hline 1 & $.085^{\mathrm{a}}$ & .007 & -.117 & .54505 \\
\hline
\end{tabular}

a. Predictors: (Constant), Suku Bunga

Interest rates are one of the most influential factors in the economy of a country besides inflation. Interest rates can affect the balance between public savings and investment in the real sector, further affecting the number of jobs and the unemployment rate. Furthermore, the implications can change people's income. This is usually called the multiplier effect. Therefore, setting interest rates, many consider various factors that will result from setting interest rates.

\section{Exchange rate}

The high domestic demand and supply for commodity goods and services abroad require a country to make international relations with other countries. Particularly in the state of Indonesia, which began implementing an open economy since 1969, which is from the very beginning of the implementation of Pelita I, Indonesia's economic interaction with other countries has been developing year after year and is an aspect of the economy that must be considered both in terms of regulations and its implementation system.

In carrying out economic interactions between countries, the existence of a medium of exchange is essential to facilitate the exchange process, as is the process of domestic transfer, but there is a problem of how to measure the price of a country's currency compared to the cost of another country's currency in economic activity. Therefore, the 
importance of the role of the exchange rate for a country requires various efforts to maintain the position of a country's currency exchange rate in a relatively stable state.

Currency exchange rate stability is also influenced by the exchange rate system adopted by a country. A country that utilizes a fixed exchange rate system must actively intervene in the market so that its currency exchange rate is at the desired level. Whereas a country that uses a floating exchange rate system, a currency exchange rate is entirely left to the strength of foreign exchange demand and supply. The table below is the exchange rate of US \$ from 2009 to 2019, which is as follows:

Table 3

Exchange Rate of US \$ in 2010-2019

\begin{tabular}{l|l}
\hline Years & Exchange Rate \\
\hline 2010 & 8991 \\
\hline 2011 & 9068 \\
\hline 2012 & 9670 \\
\hline 2013 & 12189 \\
\hline 2014 & 12440 \\
\hline 2015 & 13795 \\
\hline 2016 & 13436 \\
\hline 2017 & 13548 \\
\hline 2018 & 14481 \\
\hline 2019 & 14102 \\
\hline
\end{tabular}

Source: Statistics Indonesia, Statistics Central Board

Based on the table above it can be seen that the rate of the exchange rate has increased from year to year, where a very high increase occurred from 2012 to 2013 with a rise of 26.04 percent, and the highest exchange rate, namely in 2018 with an exchange rate of 1 US $\$=$ Rp.14,481. The US $\$$ exchange rate on national economic growth is only 90 percent, as stated in the analysis output below:

\section{Table 4}

Coefficient of Determination of US \$ Exchange Rate on Economic Growth

\begin{tabular}{l|l|l|l|l}
\hline Model & R & R Square & Adjusted R Square & Std. Error of the Estimate \\
\hline 1 & $.950^{\mathrm{a}}$ & .903 & .891 & .17051 \\
\hline
\end{tabular}

a. Predictors: (Constant), Kurs

Developing countries are very vulnerable to exchange rate fluctuations. Fluctuations in exchange rates will impact economic growth because it affects the financial balance of banks and companies that have foreign debt denominated in foreign currencies. A sharp exchange rate depreciation will increase external debt in the domestic exchange rate, increasing the possibility of default and crisis. A stable exchange rate system is an essential component for stable and prosperous economic growth. Stability is the main advantage of a fixed exchange rate because the exchange rate between currencies does not change based on market conditions. Therefore, it can create a stable business climate that is profitable for trade and investment. On the other hand, the floating exchange rate allows the central bank to conduct more independent monetary policies, which are very important for controlling the economy. 


\section{Amount of Money Circulating}

Money in circulation is the amount of currency issued and circulated by the central bank consisting of coins and banknotes, including quasi money or near money, which includes time deposits, savings deposits, and currency accounts (savings deposits) foreign domestic private property. This is because quasi money can be converted into cash, which functions the same as currency.

Money Supply is the monetary system (Central Bank, Commercial Bank, and Rural Credit Bank / BPR) to the domestic private sector (not including the central government and non-residents). Obligations that are a component of the Money Supply consist of currency held by the public (excluding commercial banks and rural banks), demand deposits, quasi money owned by the domestic private sector, and securities other than shares issued by the monetary system owned by the local private sector with the remaining time is up to one year. The money supply depends on the monetary base, the depositreserve ratio, and the currency-deposit ratio. The monetary base model, the reserve-deposit ratio, and the currency-deposit ratio are the money supply models below the bank's fractional reserves. (Mankiew, 2003) The amount of money in circulation nationally in a decade from 2010 to 2019 can be seen in the following table:

Table 5

Total Money Supply (JUB) in 2010-2019 (billion)

\begin{tabular}{l|l}
\hline Tahun & JUB \\
\hline 2010 & $2,471,206$ \\
\hline 2011 & $2,877,220$ \\
\hline 2012 & $3,307,507$ \\
\hline 2013 & $3,730,197$ \\
\hline 2014 & $4,173,327$ \\
\hline 2015 & $4,548,800$ \\
\hline 2016 & $5,004,977$ \\
\hline 2017 & $5,419,165$ \\
\hline 2018 & $5,760,046$ \\
\hline 2019 & $5,937,500$ \\
\hline
\end{tabular}

Source: Statistics Indonesia, Statistics Central Board

Based on the table above, it can be seen that the amount of money that has been increasing has increased from year to year, where a very high increase occurred from 2015 to 2016 with a rise of 10 percent with a difference of Rp 456,177 (billion). The impact of the money supply on national economic growth is only 76.8 percent as stated in the output of the analysis below:

Table 6

Coefficient of Determination of the Amount of Money Circulating on Economic Growth

\begin{tabular}{l|l|l|l|l}
\hline Model & R & R Square & Adjusted R Square & Std. Error of the Estimate \\
\hline 1 & $.877 \mathrm{a}$ & .768 & .739 & .26327 \\
\hline
\end{tabular}

a. Predictors: (Constant), Jumlah Uang Beredar

According to Dornbusch, in the short run, the increase in money supply growth will have an impact on rising inflation and output levels, but the increase is lower than the growth of the money supply. While money growth rates are usually constant in the long 
run, expectations have been adjusted to actual inflation and output so that it can be said that without additional money supply, the increase will not occur.

\section{Inflation}

A country's economy can be said to be healthy if its economic growth is stable and shows a positive direction. This is reflected in macroeconomic activity. One of the macroeconomic indicators to see the stability of a country's economy is inflation. From an economic perspective, the increase is a monetary phenomenon in a country where the rise and fall of inflation tend to cause economic turmoil because inflation affects economic growth.

Macro variables strongly influence price stability in an economy in the marketplace, therefore, this inflation rate is usually used as an indicator of economic stability. Inflation can cause a decline in real household income, especially for fixed income workers. The increase can also reduce real economic growth, encourage unemployment, and in the long run, can lead to social instability. Nevertheless, the rate of inflation should not be kept as low as possible because it is necessary to increase prices in the economic mechanism in society. With the increase in prices of goods and services will encourage people to carry out production activities so that the economy can be supported to increase national production activities. The inflation rate that occurred in Indonesia in the last decade of 2010-2019, as shown in the following table:

Table 7

Inflation Rate in 2010-2019

\begin{tabular}{l|l}
\hline Year & Inflasi \\
\hline 2010 & 5.13 \\
\hline 2011 & 5.38 \\
\hline 2012 & 4.28 \\
\hline 2013 & 6.97 \\
\hline 2014 & 6.42 \\
\hline 2015 & 6.38 \\
\hline 2016 & 3.53 \\
\hline 2017 & 3.81 \\
\hline 2018 & 3.20 \\
\hline 2019 & 3.03 \\
\hline
\end{tabular}

Source: Statistics Indonesia, Indonesian Agency

Based on the table above, it can be seen that the inflation rate has fluctuated from year to year, where a very high increase occurred from 2012 to 2013, with a rise of 62.8 percent. The impact of the inflation rate on economic growth nationally is only 4.3 percent, as indicated in the output of the analysis below:

Table 8

Coefficient of Determination of Inflation Rate on Economic Growth

\begin{tabular}{l|l|l|l|l}
\hline Model & $\mathbf{R}$ & R Square & Adjusted R Square & Std. Error of the Estimate \\
\hline 1 & $.206^{\mathrm{a}}$ & .043 & -.077 & .53527 \\
\hline
\end{tabular}

a. Predictors: (Constant), Inflasi

Inflation is an economic phenomenon which is feared by many countries including Indonesia itself because if the rate of inflation cannot be suppressed, it will have an impact 
on other economic indicators, for example, it will result in high unemployment so that it will also indirectly have an effect on economic growth caused by low national production.

\section{Investation}

According to Todaro (2000: 137-138), investment plays a vital role in driving the nation's economic life, because capital formation increases production capacity, increases national income and creates new jobs, in this case, will further expand employment opportunities. Furthermore, Mankiw (2003: 61) states that technological innovation is one of the factors that can increase investment demand.

Investment can also be interpreted as spending or spending by investors or companies to buy capital goods and equipment to increase the ability to produce products and services available in the economy. In the case of investment or investment, investment or investment is divided into domestic investment (PMDN) and foreign investment (PMA). The graphs of the development of the value of local investment (PMDN) and foreign investment (PMA) can be seen in the table below::

Table 9

Value of investment nationally in 2010-2019 (billion)

\begin{tabular}{l|l|l|l}
\hline Years & Investment LN & Investment DN & Total Investment \\
\hline 2010 & 16214 & 60626 & 76840 \\
\hline 2011 & 19474 & 76000 & 95474 \\
\hline 2012 & 24564 & 92182 & 116746 \\
\hline 2013 & 28617 & 128150 & 156767 \\
\hline 2014 & 28530 & 156126 & 184656 \\
\hline 2015 & 29276 & 179466 & 208742 \\
\hline 2016 & 28964 & 216231 & 245195 \\
\hline 2017 & 32240 & 262350 & 294590 \\
\hline 2018 & 29308 & 328604 & 357912 \\
\hline 2019 & 28209 & 386498 & 414707 \\
\hline
\end{tabular}

Source: Statistics Indonesia, Statistics Indonesia Central Board

Based on the table above, it can be seen that the level has fluctuated from year to year, where a very high increase occurred from 2017 to 2018 with a rise of 25 percent with an increase in investment of $\mathrm{Rp} 66,254$ (billion). The impact of the total expenditure on national economic growth is only 60.8 percent, as stated in the analysis output below:

Table 10

Coefficient of Determination of the Amount of Investment on Economic Growth

\begin{tabular}{l|l|l|l|l}
\hline Model & R & R Square & Adjusted R Square & Std. Error of the Estimate \\
\hline 1 & $.780^{a}$ & .608 & .559 & .34250 \\
\hline
\end{tabular}

a. Predictors: (Constant), Investasi

Indonesia is a country that has excellent prospects for investment or investment, both investment or domestic investment (PMDN), as well as an investment or foreign investment (PMA). If the flow of finance to a country takes place continuously and in the long run and is accompanied by a highly competitive economy, then investment will increase supply by increasing the stock of existing capital. Furthermore, this increase in capital stock will enhance the community's ability to produce output or carry out production activities that increase economic activity in a particular country in Indonesia. 


\section{Economic growth}

One of the main goals of a country's developmenti is high economic growth. Why is that because an indicator of the success of a country's development is high economic growth. (Todaro, 2005) Economic growth is a process of increasing output per capita in the long run. Three aspects need attention: process, per capita output, and long term. Economic growth is a process, not a financial picture at a time. Here can be seen the dynamic aspects of an economy, which is to know how the economy develops or changes from time to time. Economic growth is associated with an increase in output per capita. There are two sides to things that are the total output side and the total population. Output per capita is the total output divided by the community. So the process of increasing production per capita will inevitably be analyzed by looking at what happens with total production on the one hand and the population on the other. The condition of Indonesia's economic growth from 2010-2109 the authors describe in the following table and graph:

Table 11

National Economic Growth in 2010-2019

\begin{tabular}{l|l}
\hline Years & Economic Growth \\
\hline 2010 & 6.22 \\
\hline 2011 & 6.17 \\
\hline 2012 & 6.03 \\
\hline 2013 & 5.56 \\
\hline 2014 & 5.02 \\
\hline 2015 & 5.04 \\
\hline 2016 & 5.03 \\
\hline 2017 & 5.07 \\
\hline 2018 & 5.17 \\
\hline 2019 & 5.02 \\
\hline
\end{tabular}

Source: Statistics of Indonesia

The table above provides information and a picture of the condition of Indonesia's economic growth nationally in the last ten years 2010-2019 experiencing a declining trend wherein 2010 the national economic growth was 6.22 percent, but in 2019 it fell to 5.02 percent. To see the economic growth in the decade of 2010-2019, whether stationery or not, stationery data tests were carried out as seen in the following output:

\section{Figure 1}

\section{OutPut Test Stationery}

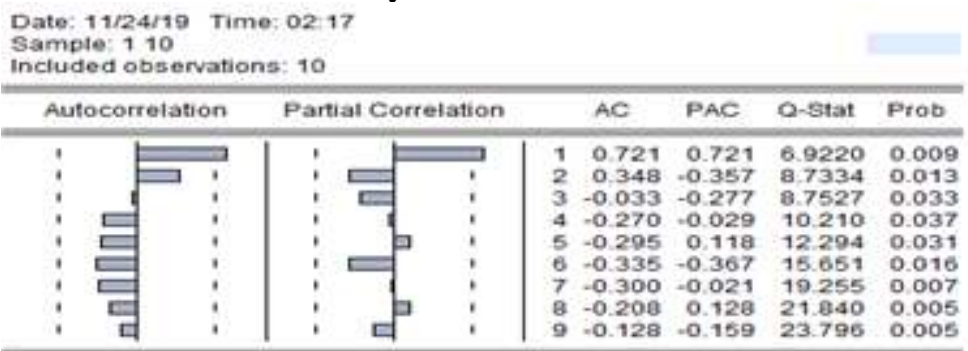

Source: Correlogram eviews output

Based on the above results, it is explained that:

1. The autocorrelation graph in the first lag is outside the Bartlett line and decreases exponentially or slowly, getting smaller, and if it continues, the figure will come out 
again from the Bartlett line, even though the bar graph moves to the left. Bartlett lines are lines marked by dashed lines on both sides of the midline, both on the autocorrelation and partial autocorrelation charts.

2. The autocorrelation coefficient value is significant at 0.721 (from likely -1 to +1 ) and decreases to lag 9 .

3. The Q statistic's significance against the 9th lag is 23,796, which is far higher than the Kai Squared statistic value.

The probability value from lag 1 to lag 9 is very close to zero, meaning less than $=5 \%$. In other words, the data is not stationary. This is reinforced if we look at the foreign debt line graph on graph 4, where the results are not flat; inevitably, the data is not stationary.

The condition of Indonesia's economic growth in 2018 is the best growth in the last 4 years, amounting to 5.17 percent. Even though the government initially targeted Indonesia's economic growth in 2018 of 5.4 percent, which was later revised to 5.2 percent. The condition of Indonesia's economic growth, which tends to stagnate, makes the government have to think about plans so that Indonesia is not trapped in a middle-income trap. If you only rely on fiscal and monetary policies, Indonesia's growth is estimated not to be more than 5 percent. To get out of the middle-income trap (middle income trap), economic growth is needed around 7 percent

\section{Discussion}

Raising interest rates is the central bank's primary tool to fight inflation. Making borrowing costs more expensive, the amount of money circulating in the community will decrease, and economic activity will decrease. The opposite can happen. The fall in interest rates will cause borrowing costs to become even cheaper. Investors will be inclined to expand their business or a new investment, and consumers will increase their spending. Thus the economic output will increase, and more labor is needed. Also, investment in the stock market will rise. However, economic activity that is too high will cause inflation to increase. The higher the inflation rate will cause the higher prices of goods and services. The purchasing power of money will decrease. Another result of lowinterest rates is the decline in bond sales because the yield provided will be relatively low. However, the central bank will not necessarily raise interest rates. The central bank will see whether things will be better if interest rates are raised, especially if there is a recession.

Changes in the BI Rate can also affect the exchange rate. This mechanism is often called the exchange rate channel. An increase in the BI Rate, for example, will encourage growth in the difference between interest rates in Indonesia and foreign interest rates. The widening of the gap in interest rates encourages foreign nvestors to invest capital in Indonesia's financial instruments, such as SBI, because they will get higher returns. This foreign capital inflows will, in turn, encourage appreciation of the Rupiah exchange rate. The Rupiah's satisfaction results in lower prices for imported goods and our export goods abroad become more expensive or less competitive so that they will encourage imports and reduce exports. The decline in net exports will have an impact on declining economic growth and economic activity.

Changes in the BI Rate will affect the macroeconomy through changes in asset prices. An increase in interest rates will reduce the costs of assets such as stocks and bonds, thereby lowering individuals' and companies' wealth, which in turn reduces their ability to carry out economic activities such as consumption and investment. The impact of changes in interest rates on economic activity also affects public expectations of inflation 
(expectations). A decrease in interest rates is expected to encourage economic activity, and ultimately inflation helps workers to anticipate rising inflation by asking for higher wages. Producers will eventually charge this wage to consumers through price increases.

The increase in interest rates carried out by the Central Bank will be responded by market participants and investors to take advantage of the moment to increase production and invest. Along with that, it will also impact the number of production increases, and the labor force will also increase. As a result, exports have increased, and unemployment has declined so that foreign exchange that enters the country strengthens the dollar against other currencies. Vice versa, if interest rates only fall, industrial production will decrease because producers will limit losses. If the number of production decreases, it will weaken the currency.

One crucial indicator in analyzing the Indonesian economy is the rupiah's exchange rate against the US dollar. The exchange rate is essential because it has a broad impact on the economy as a whole. Therefore, the exchange rate movement becomes a serious concern by the monetary authority to monitor and control it, especially concerning factors affecting the exchange rate of the rupiah. Since Indonesia has used a free-floating exchange rate policy system implemented by the imonetary authority to control exchange rate fluctuations, it has become even more critical.

Money is determined as a means of payment in international trade, the existence of differences in the value of currencies between countries that carry out foreign trade activities results in exchange rates or differences in exchange rates. The increase or decrease in the exchange rate of the Rupiah against the US Dollar has been going on since 2016 until the beginning of 2018, this is not a new phenomenon, but its impact will be significantly felt on national export and import activities. The effect of the exchange rate movement on the economy, which can occur the exchange rate, positively impacts export demand so that the trade balance increases.

The money supply is positively related to Indonesia's economic growth. There is a stable long-term relationship between government policy and economic growth. In the short term, the money supply and credit as monetary variables have a short-term commercial growth relationship. This means that in the same period, the money supply will positively affect economic growth. This means that as the money supply increases, the growth of the Indonesian economy will increase. The money supply has a positive and significant effect on economic rowth. Based on Keynes's hypothesis, that money supply has a positive influence on output and economic growth. If there is an excess of money supply, Bank Indonesia will adopt a policy of (reducing) interest rates. This condition encourages investment, which in turn will create an increase in output and trigger economic growth.

The impact of inflation on the economy as a whole, for example, the prospect of long-term economic development, will worsen, increase disrupts financial stability by damaging the long-term plans of economic actors. If inflation cannot be handled, it will be difficult to control; inflation tends to accelerate and harm individuals and society, creditors/debtors, and producers. The impact of inflation on individuals and culture include: 1) Decreasing levels of community welfare. Inflation causes people's purchasing power to decrease or even lower, especially for people who have a steady income, wage increases are not as fast as rising prices, then this inflation will reduce the real wages of every individual who has a fixed income. 2) Worsening income distribution for people whose income will still face a decline in the actual value of their income and the owners of 
wealth in the form of money will also decrease. Thus inflation will cause the division of income between fixed income groups and owners of fixed assets will become increasingly uneven.

Investment is the first step in production activities and is a factor in increasing economic growth. Thus, finance, in essence, is also the first step in economic development activities. The dynamics of investment or investment affect economic growth, reflecting the high or sluggish economic development. Investment activities will produce investments that will continue to increase the capital stock (capital stock). Furthermore, an increase in capital stock will increase productivity, capacity, and quality of production, which will drive the rate of economic growth.

One of the efforts made by Indonesia to encourage economic growth is to grow the investment sector. Investment is one of the most critical factors in determining economic growth and plays a significant role in a country's economic activities. Investment or investment is the purchase of capital goods and equipment and production equipment to increase the ability to produce the products and services needed. Economists say that investment and exports are the engines of economic "engine of growth" in Indonesia.

\section{Conclusion}

The interest rate (BI Rate) has an impact rate on national economic growth in the decade 2010-2019 of only 7 percent. Impact of US \$ exchange rate on the domestic economic growth of only 90 percent 3) Impact of the amount of money in circulation on the national economic growth of only 76.8 percent, 4) Impact of inflation rate on the domestic economic growth of only 4.3 percent 5) impact of total investment in local economic growth is only 60.8 percent. Thus the main objective of monetary policy is more emphasis on price stability based on several considerations. First, with output determined by long-term economic capacity, any strategy that drives economic growth will create inflation (the short-run Phillips-curve) so that it will not affect real economic growth. Second, the rational commercial agent understands that the surprise actions of policymakers in encouraging the economic growth that support inflation can lead to time consistency problems. Third, monetary policy influencing economic variables takes a long time and has a lag. Fourth, price stability can promote the creation of a better economic climate because it will reduce costs from inflation.

\section{Reference}

[1]. Bernanke, B. S. and Gertler, M. (1995). Inside The Black Box, The Credit Channel Of Monetary Policy Transmission. Journal of Economic Perspectives 9: 27-48.

[2]. Carlino, G. and DeFina, R. H. (1998). The Differential Regional Effects Of Monetary Policy. Review of Economics and Statistics 80: 572-587.

[3]. Carlino, G. and DeFina, R. H. (1999). The Differential Regional Effects Of Monetary Policy Evidence from the U.S. States. Journal of Regional Science 39: 339-358

[4]. Cioran, Z. (2014). Monetary Policy, Inflation and the Causal Relation between the Inflation Rate and Some of the Macroeconomic Variables. Procedia Economics and Finances, 391- 401

[5]. Clements, B., Kontolemis, Z., Levy, J., and Joaquim, V. (2001) Monetary policy under EMU Differences in the transmission mechanism. IMF, Working Paper no. 01/102.

[6]. De Grauwe, P. and Storti, C. C. (2004) The Effects Of Monetary Policy: A Meta-Analysis CESIFO, Working Paper no. 1224. 
[7]. Dornbusch, R., and F. Stanley, 1991, Macroeconomics, diterjemahkan oleh J. Mulyad Jakarta : Penerbit Erlangga

[8]. Hameed, I., \& UME-Amen. (2011). Impact of Monetary Policy on Gross Domestic Product (GDP). Interdisciplinary Journal of Contemporary Research in Business [e-journal] 3(1).

[9]. Krugman, Paul R dan Maurice Obstfeld. (1994) Ekonomi Internasional :Teori dan. Kebijakan, Jakarta, PT Rajagrafindo Persada,

[10]. Litteboy, Bruce and Taylor, B John.(2006). Macroeconomics. Australia: John Wiley \& Sons Ltd.

[11]. Mankew, N. Gregory. (2006). Pengantar Ekonomi Makro, Edisi Ketiga. Salemba Empat Jakarta: Erlangga..

[12]. Mankiw, N. Gregory. (2003) Teori Makroekonomi Edisi Kelima. Jakarta : Erlangga.

[13]. Mishkin, F.S. (2004). The Economics of Money, Banking and Financial Markets. Seventh Edition. International Edition, New York: Pearson Addison Wesley Longman.

[14]. Nanga, Muana. (2005) Makro Ekonomi: Teori, Masalah, dan Kebijakan. Edisi Kedua. PT Raja Grafindo Persada. Jakarta.

[15]. Nopirin. (2016). Ekonomi Moneter. Yogyakarta: BPFE yogyakarta.

[16]. Owyang, M. T. and Wall, H. J. (2004). Structural Breaks And Regional Disparities In The Transmission Of Monetary Policy. Federal Reserve Bank of St. Louis, Working Paper no. 2003-008

[17]. Peersman, G. (2004). The Transmission Of Monetary Policy In The Euro Area: Are The Effects Different Across Countries? Oxford Bulletin of Economics and Statistics 66(3): 285-308

[18]. Perlambang, H. (2012). Analisis Pengaruh Jumlah Uang Beredar, Suku Bunga Sbi, Nilai Tukar Terhadap Tingkat Inflasi. vol.19 no.2.

[19]. Ramaswamy, R. and Sløk, T. (1998). The Real Effects Of Monetary Policy In The European Union: What Are The Differences? Staff Papers - International Monetary Fund 45(2): 374-396.

[20]. Ridhwan, M. M., Nijkamp, P., Rietveld, P. and de Groot, H. L. F. (2008). Regional Development And Monetary Policy: A Review Of The Role Of Monetary Unions, Capital Mobility And Locational Effects. Amsterdam, research memoranda no. 0007.

[21]. Solikin, M. Juhro (2005), Analisis Kebijakan Moneter Dalam Model Makroekonometrik Struktural Jangka Panjang: Structural Cointegrating Vector Autoregression., Buletin Ekonomi Moneter dan Perbankan, September, Vol. 8 (2): 191 - 229.

[22]. Sukirno, S. (2000). Makroekonomi modern. Jakarta: PT Raja Grafindo Persada

[23]. Todaro, Michael P. (2000) Pembangunan Ekonomi di Dunia Ketiga. Erlangga.Jakarta 